\title{
BREVE NOTA SOBRE O TEMPO TRÁGICO NO FUTEBOL
}

\author{
TEODORO RENNÓ ASSUNÇÃO \\ Faculdade de Letras \\ Universidade Federal de Minas Gerais
}

para a Filomena, mestra e amiga de toda uma vida

Resumo: Esta nota quase jornalística visa a apresentar sucintamente para além do tempo (unidirecional e irreversivel) de duração de uma partida de futebol - a dimensão de um tempo não homogêneo e diferenciado no futebol segundo as ocasiões ou chances de gol nunca de todo previsiveis e que podem acontecer, mudando o resultado da partida, até o apito final.

Palavras-chave: Nota; tempo trágico; futebol.

Para começar com o óbvio (nem sempre bem percebido), direi que uma partida de futebol de campo - em campo grande, onde se afrontam dois times de onze jogadores visando o gol - tem, assim como os limites espaciais do campo (além dos quais o jogo não está mais valendo), limites temporais bem definidos que são os dois tempos, separados por quinze minutos de intervalo, de quarenta e cinco minutos cada um e mais alguns possíveis minutos de acréscimo compensatório. Mas, diferentemente, por exemplo, do que ocorre no basquete, os quarenta e cinco minutos são corridos e não interrompidos quando a bola sai de campo ou o jogo é paralisado, ou seja: eles se assemelham ou coincidem, enquanto ocorrem, com o tempo real, que só deixa de continuamente vir a ser no instante da morte. E, assim como o tempo real (ou com ele coincidindo), este contínuo vir a ser tem uma única e irreversível direção, representada espacial e triadicamente como uma linha que vai do passado para o presente em direção ao futuro, sem jamais retornar.

Dentro deste primeiro e básico enquadramento, no entanto, atua uma outra dimensão do tempo, que, no futebol, é enfatizada pela freqüência (maior do que a em outros esportes coletivos de disputa entre dois times) das chances de jogadas perigosas, nem sempre determinadas apenas pela habilidade dos que ata- 
cam ou a inabilidade dos que defendem (mesmo que sejam também decisivas), chances que podem ou não ser aproveitadas, e finalmente resultar ou não em gol. Pois são muitas as possibilidades em um jogo entre dois times adversários de onze jogadores que devem fazer continuamente circular com os pés a bola (com exceção do goleiro e de quem cobra lateral, mas somente por alguns segundos) sem poder propriamente segurá-la. As chances (que aí ocorrem) representam e cristalizam, como dimensão temporal característica do agora humano, primeiramente $a$ indeterminação fundamental do futuro, ou seja: a possibilidade de as coisas (ou, mais propriamente, os eventos) serem de uma ou de outra maneira, ainda que certamente nada do que já aconteceu possa deixar de ter acontecido e nem o presente de ser a mais imediata continuidade disso, como sempre bem indica o placar. Pois, como foi sempre evidente, o jogo (ou a possibilidade, ao menos, de mudança do placar, quando não uma mudança do resultado como vitória, empate ou derrota) de cada partida de futebol permanece sempre em aberto até o apito final, verdade (ou lugarcomum) em que o futebol parece apresentar um corte condensado agonístico e coreográfico da vida humana (o mais verossímil possível, porque é também a vida mesma) enquanto básica abertura e indeterminação, definida de uma vez por todas apenas com a morte.

Mas, em sua irrupção súbita (que pode mudar radicalmente a situação presente), as chances representam também cristalizadamente a não igualdade ou descontinuidade do tempo, enquanto sucessão de eventos singulares muito diferenciados (isto é: mais ou menos perigosos) em relação à possibilidade máxima (que é também a cada vez única) do gol, que altera o padrão mesmo da realidade do jogo, com a mudança do placar e o seu recomeço no meio do campo, como se reiniciando a partida. O gol (do inglês goal, "meta" ou "objetivo") é, enquanto aquilo que se busca, também um evento (a entrada da bola dentro do espaço interno das traves, o "alvo"), mas um evento máximo e reconfigurador que, de algum modo, subordina os outros, segundo o modo mais ou menos direto ou incisivo como a ele levam, ou seja: como são perigosos. $\mathrm{O}$ conjunto de uma partida, como campo de possibilidades de advento destas chances para a chance máxima do gol, permite, assim, a apreensão de um tempo diferenciado, como oportunidade ou chance, que foi formulada com felicidade pelos Gregos antigos como o kairós, a "ocasião favorável", que é sempre única, não de todo previsível e decisiva, segundo o seu bom ou mau aproveitamento, para o resultado de uma disputa ou, mais genericamente, para o curso subseqüente dos eventos.

Esta representação do tempo, que desautoriza o modelo não só de uma pretensa uniformidade objetiva, mas também o de uma continuidade regular e 
sem sobressaltos, parece centrada em uma percepção e conceituação do "evento" como aquilo que a cada vez e singularmente sucede ou acontece, o que também foi formulado com acuidade pelos Gregos antigos (em sua língua perspicaz) como a týkhe, o "acontecimento", o (no sentido neutro) "sucesso", que também poderia ser traduzido como "acaso". Uma tal categoria inclui, por definição, todos aqueles detalhes ou circunstâncias aparentemente insignificantes, mas que, quanto ao resultado, são decisivos e desestabilizadores, dando a impressão, aos que os presenciam ou por eles são atravessados, de algo que escapa a seu controle. É figurado assim aquilo que - sobretudo em uma situação de relativo equilíbrio das duas forças adversárias (em preparo físico, habilidade e vontade de vencer) - irrompe e consagra de um modo misterioso (e não apenas por seus méritos) o vencedor. Para o pensamento mais arcaico da Ilíada, o "evento" decisivo que surpreende é sempre figurado como a manifestação de um deus (ainda que o mortal não saiba bem qual deles), e a "glória", enquanto estrela momentânea da vitória ou kûdos (que antecede e justifica a "fama" ou "renome", o kléos), é pensada como uma graça inconstante e caprichosa concedida pela divindade.

A efetividade soberana do acontecimento, exemplificada maximamente pelo gol (mas, em um outro e menor plano, também pelas jogadas bem realizadas que não necessariamente resultam em gol), parece, nesta perspectiva, tornar totalmente inútil e despropositada a questão da justiça ou injustiça de um gol ou de um placar final de uma partida (a não ser que haja um ou mais erros grosseiros de arbitragem), pois vitorioso é, por definição e segundo as conhecidas regras do jogo, aquele dos dois times que faz um número maior (e leva um menor) de gols, mesmo que se possa reconhecer eventualmente que um time derrotado teve o domínio técnico e um maior número de chances claras de gol durante a partida, já que, como se sabe, sem a conversão em gols esta superioridade é insuficiente e inefetiva e só tem um valor simbólico e consolador.

E, apesar de não renunciar à idéia da responsabilidade dos agentes por aquilo que resulta de suas ações (o preparo físico, a habilidade e o entrosamento do time continuando a ser percebidos, assim, como essenciais para se obter a vitória), esta representação da descontinuidade não explica aquilo que (nunca de modo inteiramente certo) advém (isto é: acontece) em campo, apenas pelo mérito dos que disputam ou jogam, abrindo então espaço para a surpresa e a admiração diante do que, como algo maior e não de todo previsível e imaginável, acaba sucedendo (e se tornando também, uma vez sucedido, uma estranha necessidade). Assim, pois, também a falha ou o erro (sobretudo se eles são por muito pouco) dificilmente parecem atribuíveis apenas aos agentes humanos, o que pode dar, então, à derrota 
- complementarmente ao brilho sorridente da vitória - a dimensão de uma tragédia (aristotelicamente, "uma passagem imerecida da boa para a má fortuna, a partir de algum erro"), que é justamente o que traz - enquanto possibilidade negativa de algum modo sempre presente - o maior e mais ambíguo sabor ao futebol.

Enfim, como faltaram exemplos para dar mais sabor a esta breve tentativa de construção de uma hipótese sobre o tempo (ou o evento) no futebol, o ensaísta, já um pouco cansado, levanta-se da cadeira, junto ao lap-top, sai do escritório ou gabinete e entra na saleta da ficção, onde ouve, logo ao entrar, da boca de um velho amigo, que bebe tranqüilo com outros chegados uma pilsen-extra num boteco de bairro belo-horizontino: "a chegada ligeiramente atrasada de Barbosa no gol de Giggia contra o Brasil na final de 50"; "o passo à frente dado por Júnior no escanteio do terceiro gol (também de Rossi) no Brasil e Itália de 1982"; "o pênalti perdido por Zico na prorrogação de Brasil e França em 1986”; "a arrumada de meião de Roberto Carlos no gol de Henry no Brasil e França de 2006”; e - após dar alguns exemplos do seu time: Cruzeiro, Atlético ou América?, o leitor pode escolher... - o amigo começa a narrar, com os olhos úmidos de lágrimas, lances ainda mais surpreendentes e decisivos presenciados por ele no futebol de várzea belo-horizontino dos anos 70 (sobretudo a, segundo ele, inesquecível Copa Arizona), citando nomes de jogadores "fabulosos" que o ensaísta nunca ouvira antes e de que, mesmo agora, invadido por uma grande onda Messi-Neymar, tem grande dificuldade de se lembrar.

Résumé: Cettte note presque journalistique veut présenter de manière succinte - au délà de la durée (unidirectionnelle et irréversible) d'un match de football - la dimension d'un temps non homogène et differencié dans le football selon les occasions ou chances de but jamais entièrement prévisíbles et qui peuvent advenir, en changeant le résultat du match, jusqu'au dernier sifflet de l'arbitre.

Mots-clés: Note; temps tragique; football. 